\title{
Analisis Pengaruh Biaya Perkuliahan, Biaya Promosi dan Faktor Eksternal (Uncontrollable) Terhadap Penerimaan Jumlah Mahasiswa Baru di Kampus STMIK Atma Luhur Pangkalpinang
}

\author{
Seno Hadi Saputro \\ STMIK Atma Luhur \\ Jl. Jend. Sudirman, Selindung, Pangkalbalam, \\ Pangkalpinang, Kepulauan Bangka Belitung 0717-433506 \\ seno.hadi@atmaluhur.ac.id
}

\author{
Hengki \\ STMIK Atma Luhur \\ Jl. Jend. Sudirman, Selindung, Pangkalbalam, \\ Pangkalpinang, Kepulauan Bangka Belitung 0717-433506 \\ hengki@atmaluhur.ac.id
}

\begin{abstract}
This research is performed in order to test the influence of tuition, promotion costs and macro variable (uncontrolable) toward the number of new admissions. Methodology research as the sample used purposive sampling and this research in STMIK AtmaLuhur. Data analysis with multiplier regression of panel data common effect method. Empirical evidence of analysis show as tuition, promotion costs, inflation, kurs, BI Rate not influence toward the number of new amissions Strata 1 in STMIK AtmaLuhur. Inflation, Kurs, Bi Rate not influence toward the number of new admissions Diploma 3 while tuition have negative influence toward the number of new admissions and promotion costs have positive influence toward the number of new admissions Diploma 3 in STMIK Atma Luhur.
\end{abstract}

Keyword : tuition, promotion costs, macro variable and number of new admissions

Abstrak-- Penelitian ini untuk menguji pengaruh biaya perkuliahan, biaya promosi dan variable makro terhadap jumlah penerimaan mahasiswa baru. Metodologi peneliatan menggunakan purposive sample dan penelitian dilakukan di STMIK Atma Luhur. Analisis data menggunakan regresi berganda dengan panel data metode common effect. Hasil penelitian menunjukkan bahwabiaya perkuliahan, biaya promosi, inflasi, kurs, BI Rate tidak mempengaruhi jumlah penerimaan mahasiswa baru Strata 1 di STMIK Atma Luhur. Inflasi, kurs, BI Rate tidak mempengaruhi terhadap jumlah penerimaan mahasiswa baru diploma 3 sedangkan biaya perkuliahan berpengaruh negative terhadap jumlah penerimaan mahasiswa baru dan biaya promosi berpengaruh positif terhadap jumlah penerimaan mahasiswabaru diploma 3 STMIK Atma Luhur.

Kata Kunci: Biaya Perkuliahan, Biaya Promosi, variable makro dan jumlah penerimaan mahasiswa baru

\section{PENDAHULUAN}

Pembangunan nasional merupakan rangkaian pembangunan seluruh aspek yang berkesinambungan meliputi kehidupan bermasyarakat, berbangsa dan bernegara.Tujuan pembangunan nasional adalah mewujudkan masyarakat adil dan makmur yang merata berdasarkan Pancasila dan Undang-Undang Dasar 1945.Salah satu aspek pembangunan adalah di bidang pendidikan. Pendidikan yang baik akan menjadikan seseorang memiliki modal investasi untuk masa depan. Dengan modal pendidikan yang baik, efeknya tidak hanya untuk jangka pendek tetapi juga untuk jangka panjang. Dampak jangka panjang yang dapat dirasakan antara lain adalah berdampak pada karir seseorang apabila sudah terjun didalam dunia kerja professional, selain itu dalam jangka pendek pendidikan dapat dijadikan suatu investasi karena salah satu alasannya adalah bahwa dengan adanya pendidikan yang baik maka ilmu yang kita peroleh dapat terus dikembangkan sesuai dengan bidang ilmu yang kita pelajari.

Perguruan tinggi merupakan salah satu jenjang dalam dunia pendidikan yang mempunyai peran sebagai institusi yang bertanggung jawab dalam menjaga daya saing bangsa.Daya saing bangsa dapat dibangun dengan baik apabila didukung oleh Perguruan Tinggi (PT) yang berkualitas, sehngga mempunyai daya saing yang kuat dalam kompetensi ekonomi global.Seiring dengan berkembangnya dunia pendidikan, perguruan tinggi dibagi menjadi dua, yaitu Perguruan Tinggi Negeri (PTN) dan Perguruan Tinggi Swasta (PTS).Perguruan tinggi negeri dikelola oleh pemerintah sedangkan perguruan tinggi swasta dikelola oleh instansi tertentu (yayasan).

Sekolah Tinggi Manajemen Informatika dan Komputer (STMIK) Atma Luhur berlokasi di Jalan Jenderal Sudirman, Selindung, Pangkalbalam, Pangkalpinang, 
Kepulauan Bangka Belitung adalah salah satu perguruan tinggi swasta yang merupakan bagian dari Kopertis Wilayah II menawarkan 4 program studi yaitu D3 Manajemen Informatika, D3 Komputerisasi Akuntansi, S1 Sistem Informasi dan S1 Teknik Informatika. STMIK Atma Luhur berfungsi untuk memberikan pelayanan pendidikan dan membantu dalam meningkatkan taraf hidup masyarakat serta diharapkan dapat dijadikan sebagai pilihan Perguruan Tinggi (PT) bagi masyarakat yang berminat untuk mendapatkan pendidikan dibidang komputer.

Penerimaan mahasiswa baru kampus STMIK Atma Luhur dari waktu ke waktu mengalami perubahan. Perubahan tersebut dapat digambarkan pada tabel 1 berikut :

Tabel 1. Penerimaan mahasiswa baru STMIK Atma Luhur Tahun 2009-2015

\begin{tabular}{|c|c|c|c|}
\hline $\begin{array}{c}\text { Tahun } \\
\text { Akademik }\end{array}$ & $\begin{array}{c}\text { Diploma 3 } \\
\text { (D-3) }\end{array}$ & $\begin{array}{c}\text { Strata 1 (S- } \\
\text { 1) }\end{array}$ & Jumlah \\
\hline $2009 / 2010$ & 273 & 236 & 509 \\
\hline $2010 / 2011$ & 182 & 508 & 690 \\
\hline $2011 / 2012$ & 135 & 448 & 583 \\
\hline $2012 / 2013$ & 76 & 339 & 415 \\
\hline $2013 / 2014$ & 47 & 280 & 327 \\
\hline $2014 / 2015$ & 41 & 481 & 522 \\
\hline $2015 / 2016$ & 39 & 362 & 401 \\
\hline
\end{tabular}

Sumber: Data dari Biro Sistem Informasi STMIK Atma Luhur

Dari data diatas dapat dijelaskan bahwa terjadi kenaikan maupun penurunan penerimaan mahasiswa baru di kampus STMIK Atma Luhur.Kenaikan maupun penurunan penerimaan mahasiswa baru di kampus STMIK Atma Luhur diduga dipengaruhi oleh biaya perkuliahan, biaya promosi maupun faktor eksternal (uncontrollable).Faktor eksternal (uncontrollable) yang digunakan dalam penelitian ini adalah inflasi, nilai tukar dolar ke rupiah (kurs) dan BI Rate.

Berdasarkan uraian diatas, maka sangat menarik untuk diadakan penelitian mengenaipengaruh biaya perkuliahan, biaya promosi dan faktor eksternal (uncontrollable) terhadap penerimaan jumlah mahasiswa baru di kampus STMIK Atma Luhur.

\section{MATERI DAN METODE PENELITIAN}

Faktor ekternal (uncontrollable) merupakan faktor yang berasal dari luar perusahaan yang tidak dapat dikontrol.Faktor tersebut adalah inflasi, nilai tukar dolar ke rupiah (kurs) danBI Rate.

Menurut Nanga (2005) dalam Salawati [1], inflasi adalah suatu gejala dimana tingkat harga umum mengalami kenaikan secara terus menerus. Menurut Sukirno [2], inflasi dibedakan menjadi sebagai berikut :

1) Inflasi ringan,

terjadi apabila kenaikan harga berada dibawah angka $10 \%$ setahun.

2) Inflasi sedang, terjadi apabila kenaikan harga berada antara $10 \%-30 \%$ setahun.
3) Inflasi berat, terjadi apabila kenaikan harga berada antara $30 \%-100 \%$ setahun.

4) Hiper inflasi (inflasi tak terkendali), terjadi apabila berada diatas $100 \%$ setahun.

Menurut A. Nasir [3], Nilai tukar suatu mata uang sebenarnya merupakan harga mata uang suatu negara terhadap mata uang asing lainnya.Nilai tukar mata uang tersebut merupakan hasil interaksi antara kekuatan permintaan (demand) dan penawaran (supply) yang terjadi di pasarvalutaasing.

BI Rate adalah suku bunga kebijakan yang mencerminkan sikap atau stance kebijakan moneter yang ditetapkan oleh Bank Indonesia dan diumumkan kepada publik. BI Rate diumumkan oleh dewan gubernur Bank Indonesia setiap rapat dewan gubernur bulanan dan diimplementasikan pada operasi moneter yang dilakukan bank Indonesia melalui pengelolaan likuiditas (Liquidity Management) di pasar uang untuk mencapai sasaran operasional kebijakan moneter[4].

Dalam penelitian ini pengambilan sampel dilakukan berdasarkan metode pengambilan sampel bertujuan (purposive sampling) yaitu teknik penentuan sampling dengan pertimbangan tertentu / Judgment Sampling dengan tujuan untuk mendapatkan sampel yang representatif sesuai dengan kriteria sampel sebagai berikut :

1) Periode pengamatan dilakukan 6 tahun berturut-turut yaitu tahun akademik 2009/2010, 2010/2011, 2011/2012, 2012/2013, 2013/2014, 2014/2015, 2015/2016

2) Periode pengamatan dilakukan pada akhir penerimaan mahasiswa baru yaitu pada tanggal 31 Agustus 2009 sampai 31 Agustus 2015

Metode penelitian yang digunakan untuk menganalisis pengaruh Biaya Perkuliahan, Biaya Promosi, Inflasi, Nilai Kurs dan BI Rate terhadap penerimaan jumlah mahasiswa baru adalah analisis data panel. Perangkat lunak yang digunakan dalam penelitian ini adalah Microsoft Excel 2007 untuk mengelompokkan data dan selanjutnya diolah menggunakan softwareEviews 6.

Metode analisis yang digunakan dalam penelitian ini adalah analisis regresi berganda dengan panel data. MenurutAgusWidarjono [5] Panel data atau disebut data longitudinal adalah sekelompok data individual yang diteliti selama rentang waktu tertentu. Panel data merupakan gabungan dari time series data dan cross section data. Model panel data terdiri dari 3 bentuk yaitu :

1) Ordinary Least Square

Metode Ordinary Least Square dikenal dengan estimasi Common effect. Dalam pendekatan ini tidak memperhatikan dimensi individu maupun waktu. Diasumsikan bahwa perilaku data antar perusahaan sama dalam berbagai kurun waktu.

2) Fixed Effect

Pengertian Fixed effect ini didasarkan adanya perbedaan intersep antara perusahaan namun intersep nya sama antar waktu (time invariant). Disamping itu, model 
fixed effect juga mengasumsikan bahwa koefisien regresi (slope) tetap antar perusahaan dan antar waktu

3) Random Effect

Didalam model ini kita akan mengestimasi data panel dimana variabel gangguan mungkin saling berhubungan antar waktu dan antar individu .

A. Pengujian Pemilihan Model dalam Pengolahan Data Panel

1) Uji Chow (Chow Test)

Uji chow dilakukan untuk memilih model yang digunakan Common Effect atau Fixed Effect. Pengujian ini dilakukan dengan hipotesa sebagai berikut :

$\mathrm{H}_{0}$ : Model Common Effect

$\mathrm{H}_{1}$ : Model Fixed Effect

Dasar penolakan terhadap hipotesa nol tersebut adalah dengan menggunakan Rumus :

Chow $=\frac{(E S S 1-E S S 2) /(N-1)}{E S S 2 /(N T-N-K)}$

Dimana :

ESS1 = Residual Sum Square hasil pendugaan model Common Effect

ESS2 = Residual Sum Square hasil pendugaan model Fixed Effect

$\mathrm{N}=$ Jumlah data cross section

$\mathrm{T}=$ Jumlah data time series

$\mathrm{K}=$ Jumlah variabel penjelas

Jika nilai Chow statistics hasil pengujian lebih besar dari $\mathrm{F}$ tabel, maka Ho ditolak, begitu juga sebaliknya.

2) Uji Hausman (Hausman Test)

Uji hausman dilakukan untuk memilih model yang digunakan Fixed Effect atau Random Effect. Pengujian ini dilakukan dengan hipotesa sebagai berikut :

$$
\begin{aligned}
& \mathrm{H}_{0} \text { : Model Random Effect } \\
& \mathrm{H}_{1} \text { : Model Fixed Effect }
\end{aligned}
$$

Jika nilai hausman hasil pengujian lebih besar dari $\mathrm{X}^{2}$ tabel, maka Ho ditolak, begitu juga sebaliknya.

3) Uji Lagrange Multiplier (LM Test)

Uji hausman dilakukan untuk memilih model yang digunakan Fixed Effect atau Random Effect. Pengujian ini dilakukan dengan hipotesa sebagai berikut :

$$
\begin{aligned}
& \mathrm{H}_{0} \text { : Model Common Effect } \\
& \mathrm{H}_{1} \text { : Model Random Effect }
\end{aligned}
$$

Jika nilai Lagrange Multiplier hasil pengujian lebih besar dari $\mathrm{X}^{2}$ tabel, maka Ho ditolak, begitu juga sebaliknya.

\section{B. Evaluasi Model Uji t (Uji Parsial)}

Uji parsial ( $t$ test) dilakukan untuk menguji signifikansi pengaruh variabel-variabel independen, yaitu Biaya perkuliahan, Biaya promosi, Inflasi, Kurs dan BI Rate secara individual terhadap variabel dependen, yaitu Penerimaan jumlah mahasiswa barutahun akademik 2009/2010, 2010/2011, 2011/2012, 2012/2013, 2013/2014, 2014/2015 dan 2015/2016. Tahap-tahap pengujiannya adalah :
Jurnal SISFOKOM, Volume 05, Nomor 01, Maret 2016

1. Merumuskan hipotesis.

$\mathrm{H}_{0}: \mathrm{b} 1 \ldots \mathrm{b} 4=0$, artinya tidak ada pengaruh antara variabel independen terhadap variabel dependen.

$\mathrm{H}_{\mathrm{a}}: \mathrm{b} 1 \ldots . . \mathrm{b} 4 \neq 0$, artinya ada pengaruh antara variabel independen terhadap variabel dependen.

2. Tingkat signifikansi yaitu 0,05 atau $5 \%$.

3.Menentukan keputusan dengan membandingkan t hitung dengan t tabel dengan kriteria sebagai berikut:

a) Jika t hitung > t tabel atau -t hitung < - t tabel, maka Ho ditolak

b) Jika $\mathrm{t}$ hitung < t tabel atau -t hitung > -t tabel, maka Ho diterima

\section{C. $\quad R$ Squared}

$R$-Squared adalah proporsi variasi dalam variabel dependen yang dapat dijelaskan oleh variabel-variabel independennya. $R$-Squared memiliki range $0 \leq R$-Squared $\leq$ 1. Jika $R$-Squared bernilai 1 maka 100 persen variasi dalam variabel dependen dapat dijelaskan oleh variabel-variabel independennya. Sedangkan jika R-Squared bernilai 0 maka variasi dalam variabel dependen tidak dapat dijelaskan oleh variabel-variabel independennya.

\section{ANALISA DAN PEMBAHASAN HASIL PENELITIAN}

A. Pengujian Pemilihan Model Data Panel Uji Chow

1) Jenjang Diploma $3(D-3)$

Chow $=\frac{(E S S 1-E S S 2) /(N-1)}{E S S 2 /(N T-N-K)}$

Chow $=\frac{(0,205383-0,076422) /(2-1)}{0,076422 /(2.7-2-5)}$

Chow $=11,8124$

Dari uji chow didapatkan hasil 11,8124 sedangkan besarnya $\mathrm{F}$ tabel dengan derajat bebas N-1 (1) dan NT-N-K (7) sebesar 5,5914. karena $\mathrm{F}$ hitung $>\mathrm{F}$ tabel maka $\mathrm{H}_{0}$ diterima. Dengan demikian dapat disimpulkan bahwa model Fixed Effect lebih sesuai digunakan didalam penelitian ini daripada Common Effect.

2) Jenjang Strata $1(S-1)$

Chow $=\frac{(E S S 1-E S S 2) /(N-1)}{E S S 2 /(N T-N-K)}$

Chow $=\frac{(0,292180-0,115946) /(2-1)}{0,115946 /(2.7-2-5)}$

Chow $=10,63976$

Dari uji chow didapatkan hasil 0 sedangkan besarnya $\mathrm{F}$ tabel dengan derajat bebas N-1 (1) dan NT-N-K (7) sebesar 5,5914. karena $\mathrm{F}$ hitung $>\mathrm{F}$ tabel maka $\mathrm{H}_{0}$ ditolak. Dengan demikian dapat disimpulkan bahwa model Fixed Effect lebih sesuai digunakan didalam penelitian ini daripada Common Effect. 


\section{B. Uji Hausman}

1) Jenjang Diploma3 (D-3)

a) Estimasi dengan metode Fixed Effect dapat dituliskan perintah sebagai berikut pada Command Editor:

Sal.ls(F) $\log (\mathrm{pmb}$ ?) $\log (\mathrm{bk}$ ?) $\log (\mathrm{bp}$ ?) $\log$ (inflasi?) $\log$ (kurs?) $\log (\mathrm{br}$ ?)

Vector beta=sal.@coefs

Matrix covar=sal.@cov

Vector b_fixed=@ subextract(beta, 1,1,5,1)

Matrix cov_fixed=@subextract $($ covar $, 1,1,5,5)$

b) Estimasi dengan metode Random Effect dapat dituliskan perintah sebagai berikut pada Command Editor:

Sal.ls(F) $\log (\mathrm{pmb}$ ?) $\log (\mathrm{bk}$ ?) $\log (\mathrm{bp}$ ?) $\log ($ inflasi?) $\log$ (kurs?) $\log ($ br?)

Vector beta=sal.@coefs

Matrix covar=sal.@cov

Vector b_random=@subextract(beta,2,1,6,1)

Matrix cov_random=@subextract(covar,2,2,6,6)

c) Menghitung nilai statistik Hausman dengan melakukan perintah berikut pada Command Editor :

Matrix b_diff=b_fixed-b_random

Matrix v_diff=cov_fixed-cov_random

Matrix

$\mathrm{H}=@$ transpose(b_diff)*@inverse(v_diff)*b_diff

Dari uji hausman didapatkan hasil 21,47501 sedangkan nilai kritis Chi Squaresdengan n-1 sebesar 1 pada $\alpha=5 \%$ sebesar 38,885. karena uji lagrange multiplier $<X^{2}$ tabel maka $\mathrm{H}_{0}$ diterima. Dengan demikian dapat disimpulkan bahwa model Common Effect lebih sesuai digunakan didalam penelitian ini daripada Random Effect.

\section{2) Jenjang Strata $1(S-1)$}

a. Estimasi dengan metode Fixed Effect dapat dituliskan perintah sebagai berikut pada Command Editor:

Sal.ls(F) $\quad \log (\mathrm{pmb}$ ?) $\quad \log (\mathrm{bk} ?) \quad \log (\mathrm{bp}$ ?) $\log$ (inflasi?) $\log$ (kurs?) $\log ($ br? $)$

Vector beta=sal.@coefs

Matrix covar=sal.@cov

Vector b_fixed=@ subextract(beta,1,1,5,1)

Matrix cov_fixed=@subextract $($ covar, $1,1,5,5)$

b. Estimasi dengan metode Random Effect dapat dituliskan perintah sebagai berikut pada Command Editor:

Sal.ls(F) $\log (\mathrm{pmb}$ ?) $\quad \log (\mathrm{bk}$ ?) $\quad \log (\mathrm{b} p$ ?) $\log$ (inflasi?) $\log$ (kurs?) $\log ($ br?)

Vector beta=sal.@coefs

Matrix covar=sal.@cov

Vector b_random=@ subextract(beta,2,1,6,1)

Matrix cov_random=@subextract $($ covar,2,2,6,6) c. Menghitung nilai statistik Hausman dengan melakukan perintah berikut pada Command Editor:

Matrix b_diff=b_fixed-b_random

Matrix v_diff=cov_fixed-cov_random

Matrix

$\mathrm{H}=@$ transpose(b_diff)*@inverse(v_diff)*b_diff

Dari uji hausman didapatkan hasil $-36,73780$ sedangkan nilai kritis Chi Squaresdengan n-1 sebesar 1 pada $\alpha=5 \%$ sebesar 38,885. karena uji lagrange multiplier $<X^{2}$ tabel maka $\mathrm{H}_{0}$ diterima. Dengan demikian dapat disimpulkan bahwa model Common Effect lebih sesuai digunakan didalam penelitian ini daripada Random Effect.

Model data panel dengan menggunakan model Common Effectsuntuk jenjang Strata 1 dan Diploma 3 ditampilkan pada tabel 2 dan tabel 3.

Tabel 2. Metode Common Effectsuntuk jenjang Strata1

\begin{tabular}{|c|c|c|c|}
\hline Variabel & Coefficient & t-Statistic & Prob \\
\hline Log B_Kuliah & 1,118634 & 1,094474 & 0,3880 \\
\hline $\log$ & $-0,088915$ & $-0,133839$ & 0,9058 \\
\hline B_Promosi & $-0,006249$ & $-0,013043$ & 0,9908 \\
\hline Log Inflasi & $-0,686852$ & $-0,655947$ & 0,5792 \\
\hline Log Kurs & 1,429320 & 0,745849 & 0,5335 \\
\hline \multicolumn{4}{|l|}{ Log BI Rate } \\
\hline R-Squared & 0,407678 & Mean & 5903915 \\
\hline Adjusted R- & $-0,776965$ & dependent var & 0,286728 \\
\hline Squared & 0,382217 & S.D. & 0,292180 \\
\hline S.E. of & 1,184467 & dependent var & \\
\hline regression & 3,135322 & Sum squared & \\
\hline & & resid & \\
\hline likelihood & & & \\
\hline Durbin & & & \\
\hline Watson stat & & & \\
\hline
\end{tabular}

Sumber : Data sekunder yang telah diolah dengan Eviews 14

Tabel 3. Metode Common Effectsuntuk jenjang Diploma 3

\begin{tabular}{|l|l|l|l|}
\hline \multicolumn{1}{|c|}{ Variabel } & Coefficient & t-Statistic & Prob \\
\hline Log B_Kuliah & $-3,399643$ & $-3,602881$ & 0,1150 \\
Log B_Promosi & 3,233288 & 2,687655 & 0,0691 \\
Log Inflasi & $-0,671730$ & $-1,706781$ & 0,2300 \\
Log Kurs & 1,384191 & 1,681626 & 0,2347 \\
Log BI Rate & 0,207792 & 0,116900 & 0,9176 \\
\hline \multicolumn{3}{|c|}{} \\
\hline R-Squared & 0,943773 & Mean dependent & 4,468110 \\
Adjusted R- & 0,831318 & var & 0,780250 \\
Squared & 0,320455 & S.D. dependent & 0,205383 \\
S.E. of & 2,418186 & var & \\
regression & 3,431686 & Sum squared & \\
Log likelihood & & resid & \\
Durbin Watson & & & \\
stat & & & \\
\hline
\end{tabular}

Sumber : Data sekunder yang telah diolah dengan Eviews 16

Nilai signifikansi uji t pada biaya perkuliahan sebesar 0,3880 untuk jenjang strata 1 dan 0,1150 untuk jenjang 
D3(sig >0,05) ini berarti biaya perkuliahan tidaksignifikan terhadap jumlah penerimaan mahasiswa baru, koefisien regresi memiliki arah positif sebesar 1,118634 untuk jenjang strata 1. Apabila dibandingkan antara $t$ hitung dan $t$ tabel maka didapatkan hasilt hitung $<2,353$ ini berarti biaya perkuliahan jenjang strata 1 tidakberpengaruh terhadap jumlah penerimaan mahasiswa baru. Sedangkan koefisien regresi memiliki arah negatif sebesar -3,399643 untuk jenjang diploma 3. Apabila dibandingkan antara t hitung dan t tabel maka didapatkan hasil -t hitung <-2,353 ini berarti biaya perkuliahan jenjang diploma 3 berpengaruh terhadap jumlah penerimaan mahasiswa baru. Dari hasil analisis tersebut jenjang strata 1 biaya perkuliahan tidak mempengaruhi jumlah penerimaan mahasiswa baru di kampus STMIK Atma Luhur. Akan tetapi untuk jenjang diploma 3 biaya perkuliahan mempengaruhi jumlah penerimaan mahasiswa baru secara negatif. Ini berarti semakin besar biaya perkuliahan maka jumlah mahasiswa baru yang diterima akan semakin berkurang begitu juga sebaliknya.

Nilai signifikansi uji t pada biaya promosi sebesar 0,9058 untuk jenjang strata 1 dan 0,0691 untuk jenjang D3(sig $>0,05$ ) ini berarti biaya promosi tidaksignifikan terhadap jumlah penerimaan mahasiswa baru, koefisien regresi memiliki arah negatif sebesar -0,088915 untuk jenjang strata 1 . Apabila dibandingkan antara t hitung dan $t$ tabel maka didapatkan hasil-2,353 $\leq \mathrm{t}$ hitung $\leq 2,353$ ini berarti biaya promosi jenjang strata 1 tidakberpengaruh terhadap jumlah penerimaan mahasiswa baru. Sedangkan koefisien regresi memiliki arah positif sebesar 3,233288 untuk jenjang Diploma 3. Apabila dibandingkan antara $\mathrm{t}$ hitung dan t tabel maka didapatkan hasil (t hitung > 2,353) ini berarti biaya promosi jenjang diploma 3 berpengaruh terhadap jumlah penerimaan mahasiswa baru. Dari hasil analisis tersebut jenjang strata 1 biaya promosi tidak mempengaruhi jumlah penerimaan mahasiswa baru di kampus STMIK Atma Luhur. Akan tetapi untuk jenjang diploma 3 biaya promosi mempengaruhi jumlah penerimaan mahasiswa baru secara positif. Ini berarti semakin besar biaya promosi maka jumlah mahasiswa baru yang diterima akan semakin meningkat begitu juga sebaliknya.

Nilai signifikansi uji t pada inflasi sebesar 0,9908 untuk jenjang strata 1 dan 0,2300 untuk jenjang D3(sig>0,05) ini berarti inflasi tidaksignifikan terhadap jumlah penerimaan mahasiswa baru, koefisien regresi memiliki arah negatif sebesar $-0,006249$ untuk jenjang strata 1. Apabila dibandingkan antara $t$ hitung dan t tabel maka didapatkan hasil-2,353 $\leq \mathrm{t}$ hitung $\leq 2,353$ ini berarti inflasi jenjang strata 1 tidakberpengaruh terhadap jumlah penerimaan mahasiswa baru. Sedangkan koefisien regresi memiliki arah negatif sebesar -0,671730 untuk jenjang Diploma 3. Apabila dibandingkan antara t hitung dan t tabel maka didapatkan hasil $-2,353 \leq \mathrm{t}$ hitung $\leq 2,353$ ini berarti inflasi jenjang diploma 3 tidak berpengaruh terhadap jumlah penerimaan mahasiswa baru. Dari hasil analisis tersebut inflasi baik jenjang strata 1 maupun diploma 3 tidak mempengaruhi jumlah penerimaan mahasiswa baru di kampus STMIK Atma Luhur.

Nilai signifikansi uji t pada kurs sebesar 0,5792 untuk jenjang strata 1 dan 0,2347 untuk jenjang D3(sig >0,05) ini berarti kurs tidaksignifikan terhadap jumlah penerimaan mahasiswa baru, koefisien regresi memiliki arah negatif sebesar -0,686852 untuk jenjang strata 1. Apabila dibandingkan antara $\mathrm{t}$ hitung dan $\mathrm{t}$ tabel maka didapatkan hasil-2,353 $\leq \mathrm{t}$ hitung $\leq 2,353$ ini berarti kurs jenjang strata 1 tidakberpengaruh terhadap jumlah penerimaan mahasiswa baru. Sedangkan koefisien regresi memiliki arah positif sebesar 1,384191 untuk jenjang Diploma 3. Apabila dibandingkan antara $\mathrm{t}$ hitung dan $\mathrm{t}$ tabel maka didapatkan hasil $-2,353 \leq \mathrm{t}$ hitung $\leq 2,353$ ini berarti kurs jenjang diploma 3 tidak berpengaruh terhadap jumlah penerimaan mahasiswa baru. Dari hasil analisis tersebut kurs baik jenjang strata 1 maupun diploma 3 tidak mempengaruhi jumlah penerimaan mahasiswa baru dikampus STMIK Atma Luhur.

Nilai signifikansi uji t pada BI Rate sebesar 0,5335 untuk jenjang strata 1 dan 0,9176 untuk jenjang D3(sig>0,05) ini berarti BI Rate tidaksignifikan terhadap jumlah penerimaan mahasiswa baru, koefisien regresi memiliki arah positif sebesar 1,429320 untuk jenjang strata 1. Apabila dibandingkan antara $t$ hitung dan t tabel maka didapatkan hasil-2,353 $\leq \mathrm{t}$ hitung $\leq 2,353$ ini berarti BI Rate jenjang strata 1 tidakberpengaruh terhadap jumlah penerimaan mahasiswa baru. Sedangkan koefisien regresi memiliki arah positif sebesar 0,207792 untuk jenjang Diploma 3. Apabila dibandingkan antara thitung dan t tabel maka didapatkan hasil $-2,353 \leq \mathrm{t}$ hitung $\leq 2,353$ ini berarti BI Rate jenjang diploma 3 tidak berpengaruh terhadap jumlah penerimaan mahasiswa baru. Dari hasil analisis tersebut BI Rate baik jenjang strata 1 maupun diploma 3 tidak mempengaruhi jumlah penerimaan mahasiswa baru di kampus STMIK Atma Luhur.

\section{$R$ Squared}

Hasil estimasi dengan menggunakan model efek common(Common Effect) menunjukkan nilai $\mathrm{R}^{2}$ atau koefisien determinasi pada hasil estimasi tersebut dapat diketahui bahwa 40,77 persen keragaman penerimaan mahasiswa baru jenjang strata 1 di kampus STMIK Atma Luhur yang menjadi sampel pada periode waktu 2009-2015 dapat dijelaskan oleh variabel bebasnya (Biaya perkuliahan, biaya promosi, inflasi, kurs dan BI Rate), sedangkan 59,23 persen dijelaskan oleh variabel lain di luar model. Variabel tersebut diduga dipengaruhi oleh minat mahasiswa baru. Sedangkan nilai $\mathrm{R}^{2}$ atau koefisien determinasi pada hasil estimasi tersebut dapat diketahui bahwa 94,38 persen keragaman penerimaan mahasiswa baru jenjang strata 3 di kampus STMIK Atma Luhur yang menjadi sampel pada periode waktu 2009-2015 dapat dijelaskan oleh variabel bebasnya (Biaya perkuliahan, biaya promosi, inflasi, kurs dan BI Rate), sedangkan 5,62 persen dijelaskan oleh variabel lain di luar model. Variabel tersebut diduga juga dipengaruhi oleh minat mahasiswa baru 
A. Kesimpulan

\section{PENUTUP}

- Pada pemilihan model data panel menggunakan model data panel Common Effect setelah dilakukan pengujian dengan menggunakan Chow test danHausman test

- Hasil uji signifikansi secara individu menunjukkan hasil :

1) Untuk jenjang strata 1 biaya kuliah, biaya promosi, inflasi, kurs dan BI Ratetidak mempengaruhi jumlah penerimaan mahasiswa baru di kampus STMIK Atma Luhur

2) Untuk jenjang diploma 3 nilai inflasi, kurs, BI Ratetidak mempengaruhi jumlah penerimaan mahasiswa baru di kampus STMIK Atma Luhur. Sedangkan biaya kuliah jenjang diploma 3 berpengaruh negatif terhadap jumlah penerimaan mahasiswa baru dan biaya promosi berpengaruh positif terhadap jumlah penerimaan mahasiswa baru di kampus STMIK Atma Luhur.

B. Saran

- Dalam penelitian mendatang perlu menambahkan variabel-variabel lain yang mempengaruhi jumlah penerimaan mahasiswa baru seperti minat, tempat tinggal mahasiswa baru, pesaing kampus dan lain sebagainya.

- Sebaiknya menggunakan periode yang lebih lama untuk mendapatkan informasi yang lebih akurat.

\section{DAFTAR PUSTAKA}

[1] Salawati, 2008, Analisis Pengaruh Inflasi dan Nilai Tukar Rupiah Terhadap Penerimaan PPN padakanwil DJP Jakarta Selatan, Skripsi, Fakultas Ekonomi Universitas Islam Negeri Syarif Hidayatullah Jakarta.

[2] Sukirno, Sadono, 2004, Teori pengantar makroekonomi, PT. Raja Grafindo Persada, Jakarta.

[3] Azwir, Nasir dan Mirza, Achmad, 2011, Pengaruh Nilai Kurs, Inflasi, Suku bunga deposito dan Volume Perdagangan Saham Terhadap Return Saham Pada Perusahaan Perbankan yang Terdaftar di Bursa Efek Indonesia, Jurnal Ekonomi Volume 19 No. 4.

[4]

www.bi.go.id/id/monetor/birate/penjelasan/contents/de fault.aspx, diakses 09 september 2016

[5] Widarjono, Agus, 2013, Ekonometrika Pengantar dan Aplikasinya Disertai Panduan Eviews, UPP STIM YKPN, Yogyakarta. 